\title{
Low-dose tacrolimus combined with donor-derived mesenchymal stem cells after renal transplantation: a prospective, non- randomized study
}

\author{
Guang-hui Pan ${ }^{1, *}$, Zheng Chen ${ }^{1,}{ }^{*}$, Lu Xu ${ }^{1}{ }^{1}$ Jing-hui Zhu ${ }^{1}$, Peng Xiang ${ }^{2}$, Jun-jie Ma ${ }^{1}$, \\ Yan-wen Peng ${ }^{2}$, Guang-hui Li ${ }^{1}$, Xiao-yong Chen ${ }^{2}$, Jia-li Fang ${ }^{1}$, Yu-he Guo ${ }^{1}$, Lei \\ Zhang ${ }^{1}$ and Long-shan Liu ${ }^{3}$ \\ 1 The Transplantation Centre, The Second Affiliated Hospital, Guangzhou Medical University, Guangzhou, China \\ ${ }^{2}$ Center for Stem Cell Biology and Tissue Engineering, SunYat-sen University, Guangzhou, Guangdong, China \\ ${ }^{3}$ Laboratory of General Surgery, The First Affiliated Hospital, Sun Yat-sen University, Guangzhou, China \\ * These authors contributed to the work equally and should be regarded as co-first authors \\ Correspondence to: Guang-hui Pan, email: panguanghvi@126.com \\ Keywords: acute rejection, calcineurin inhibitors, graft survival, mesenchymal stem cells (MSCs), nephrotoxicity, Pathology section \\ Received: September 18,2015 Accepted: January 29, $2016 \quad$ Published: February 25, 2016
}

\section{ABSTRACT}

Calcineurin inhibitors, including tacrolimus, are largely responsible for advances in allotransplantation. However, the nephrotoxicity associated with these immunosuppressants impairs patients' long-term survival after renal allograft. Therefore, novel regimens that minimize or even eliminate calcineurin inhibitors could improve transplantation outcomes. In this pilot study, we investigated the use of low-dose tacrolimus in combination with mesenchymal stem cells (MSCs), which are immunosuppressive and prolong allograft survival in experimental organ transplant models. Donor-derived, bone marrow MSCs combined with a sparing dose of tacrolimus (0.04-0.05 mg/ kg/day) were administered to 16 de novo livingrelated kidney transplant recipients; 16 other patients received a standard dose of tacrolimus (0.07-0.08 $\mathrm{mg} / \mathrm{kg} / \mathrm{day})$. The safety of MSC infusion, acute rejection, graft function, graft survival, and patient survival were evaluated over $\geq 24$ months following kidney transplantation. All patients survived and had stable renal function at the $\mathbf{2 4}$ month follow-up. The combination of low-dose tacrolimus and MSCs was as effective as standard dose tacrolimus in maintaining graft survival at least 2 years after transplantation. In addition, both groups had similar urea, urine protein, urinary RBC, urinary WBC, 24-h urine protein, and creatinine clearance rates from 7 days to 24 months after transplantation. Furthermore, no differences in the proportion of lymphocytes, CD19, CD3, CD34, CD38, and natural killer cells were detected between the control and experimental groups. None of the MSC recipients experienced immediate or long-term toxicity from the treatment. This preliminary data suggests that the addition of MSCs permits the use of lower dosages of nephrotoxic calcineurin inhibitors following renal transplantation.

\section{INTRODUCTION}

Kidney transplantation remains the most effective therapy for patients with end-stage renal disease. The major barrier to renal transplantation is acute and chronic rejection of engrafted kidneys by the recipient's immune system, hence the need for immunosuppressants. Conventional immunosuppressive drugs are generally used in transplant patients and are effective in reducing acute rejection and improving short-term outcomes. However, long-term graft survival remains a major problem after renal transplantation.

Tacrolimus is a calcineurin inhibitor that binds FKBP12, suppressing nuclear factor of activated $\mathrm{T}$ cells (NFAT) transcription of cytokines and, therefore, $\mathrm{T}$ cell function [1]. It is highly effective in preventing acute rejection and improving short-term survival in renal allograft recipients [2]. However, its adverse effects, such as nephrotoxicity, diabetogenicity, and neurotoxicity, 
constrain its long-term utility [3-5]. Thus, the elimination or minimization of calcineurin inhibitors is required to attain further improved outcomes in kidney transplantation [6]. It is necessary to develop novel immunosuppressive regimens that maximize the beneficial effects of transplantation tolerance without the aforementioned adverse effects.

Mesenchymal stem cells (MSCs) are multipotent progenitor cells that can be induced to undergo rapid proliferation and differentiation into multiple cell lineages $[7,8]$. In addition, a myriad of studies have shown that MSCs activate the proliferation of $\mathrm{T}$ cells and natural killer (NK) cells, and decrease the maturation and function of antigen-presenting cells, such as dendritic cells. The immunosuppressive capacity of MSCs makes them a potentially important therapeutic target in transplantation as they may inhibit allograft rejection and induce transplant tolerance. MSCs have been used to enhance hematopoietic stem cell engraftment and to treat graftversus-host disease (GVHD) and autoimmune disease [911]. In animal transplantation models, MSCs significantly prolonged skin and cardiac allograft survival [12-14]. Crop et al. [15] also found that infusion of donor MSCs could significantly suppress the proliferation of alloactivated T-cell subsets. These findings suggest that donor-derived MSCs may facilitate the induction of transplant tolerance, thus suppressing renal allograft rejection. Recently, Tan et al. [16] reported that the use of autologous MSCs resulted in a lower incidence of acute rejection, decreased risk of opportunistic infection, and better estimated renal function at 1 year among patients undergoing renal transplantation.

In a pilot study of 12 patients, we had previously shown that donor-derived MSCs combined with lowdose tacrolimus prevented acute rejection after renal transplantation [17]. The findings presented here are a continuation of that pilot study. In addition to the original 12 patients, 20 new patients were enrolled in this study. Sixteen patients were inoculated with MSCs and treated with low-dose tacrolimus (approximately $60 \%$ of the regular dose), while the other 16 received the standard dosage of tacrolimus. We show here that the combination of MSCs with low-dose tacrolimus was as effective as standard dose tacrolimus in preventing acute renal rejection and in maintaining graft survival at least $2 \mathrm{y}$ after transplantation.

\section{RESULTS}

\section{Baseline characteristics of all participants}

As shown in Table 1, the two groups had similar baseline characteristics, including age (mean $=29.97 \mathrm{y}$, $\mathrm{SD}=8.34$, range: $16-51 \mathrm{y})$, sex, HLA mismatching $(50 \%$ of patients had one), estimated glomerular filtration rate
$(\mathrm{eGFR}$, mean $=5.16 \mathrm{~mL} / \mathrm{min}, \mathrm{SD}=3.06 \mathrm{~mL} / \mathrm{min}$, range: $1.88-18.60 \mathrm{~mL} / \mathrm{min})$, serum creatinine $($ mean $=1211.84$ $\mu \mathrm{mol} / \mathrm{L}, \mathrm{SD}=412.50 \mu \mathrm{mol} / \mathrm{L}$, range: $369-2657 \mu \mathrm{mol} / \mathrm{L})$, urea $($ mean $=24.89 \mathrm{mmol} / \mathrm{L}, \mathrm{SD}=11.25 \mathrm{mmol} / \mathrm{L}$, range: 9.53-52.96 mmol/L), urine protein $($ mean $=2.08 \mathrm{q} / \mathrm{I}, \mathrm{SD}=$ $0.99 \mathrm{q} / \mathrm{I}$, range: $0.3-3.0 \mathrm{q} / \mathrm{I})$, urinary $\mathrm{RBC}($ mean $=44.85$ count $/ \mu \mathrm{L}, \mathrm{SD}=61.22$ count $/ \mu \mathrm{L}$, range: $0-246$ count $/ \mu \mathrm{L})$, urinary $\mathrm{WBC}($ mean $=107.59$ count $/ \mu \mathrm{L}, \mathrm{SD}=441.75$ count $/ \mu \mathrm{L}$, range: 0-2391 count $/ \mu \mathrm{L})$, lymphocytes (LN) percentage $($ mean $=24.51 \%, \mathrm{SD}=6.20 \%$, range: 3.5 $34.3 \%)$, LN count $\left(\right.$ mean $=1.5 \times 10^{9} / \mathrm{L}, \mathrm{SD}=0.39 \times 10^{9} / \mathrm{L}$, range: $\left.0.75-2.33 \times 10^{9} / \mathrm{L}\right), \mathrm{CD} 19($ mean $=11.72 \%, \mathrm{SD}=$ $4.85 \%$, range: $3.3-21.7 \%)$, CD3 (mean $=72.33 \%, \mathrm{SD}=$ 9.97\%, range: $55.1-90.4 \%), \mathrm{CD} 34($ mean $=40.52 \%, \mathrm{SD}$ $=8.1 \%$, range: $22.7-56.7 \%)$, CD38 $($ mean $=28.77 \%$, $\mathrm{SD}=8.5 \%$, range: $13.7-45.6 \%$ ), and NK levels (mean $=7.6 \%, \mathrm{SD}=3.01 \%$, range: $2.8-13.31 \%$ ). The followup duration of the two groups was also similar (mean = 28.14 months, SD = 10.8 months, range: $14-49.8$ months). However, the experimental group had higher levels of urinary RBCs than the control group. In addition, there was no difference in donors' characteristics between the two groups, including age $(P=0.183)$, gender $(P=0.473)$ and creatinine levels $(P=0.057)$.

\section{Levels of urea, urine protein, urinary $\mathrm{RBC}$, urinary WBC, 24-h urine protein and creatinine clearance rate $(\mathrm{Ccr})$ over time}

Both groups had similar changes of urea, urine protein, urinary $\mathrm{RBC}$, urinary $\mathrm{WBC}, 24-\mathrm{h}$ urine protein levels and Ccr levels over the study period (all $P_{\text {group }}$ effect $>0.05$; Table 2). In both groups, the levels of urea dropped in the first 3 months following the surgery and were maintained thereafter. Likewise, the levels of urine protein dropped after the surgery, with a maximal decrease at 1 month that was maintained. Whereas the urine RBC levels increased at day 7 following the surgery, they sharply decreased at one month after the surgery, and no significant changes were subsequently observed. The urine WBC levels dropped significantly within 3 months after the surgery and then stabilized. However, no significant changes in the concentrations of 24-h urine protein and Ccr were observed (Table 2).

\section{Changes in LN percentage, LN count, CD19, CD3, CD34, CD38 and NK cells over the study period}

A significant group effect was found for CD38 $(P$ $=0.010)$ and $\mathrm{NK}(P=0.007)$; the percentage of CD38 and NK cells was higher in control group than in the experimental group. The percentages of both CD38 and NK cells in the control group were higher than those in the experimental. The LN percentage dropped after the surgery, and increased to the baseline level in both 
Table 1: Baseline characteristics of the 32 patients

\begin{tabular}{|c|c|c|c|}
\hline & $\begin{array}{l}\text { Control } \\
(n=16)\end{array}$ & $\begin{array}{l}\text { Experimental } \\
(n=16)\end{array}$ & $P$-value \\
\hline Age (y) & $29.31(9.48)$ & $30.63(7.27)$ & 0.664 \\
\hline \multicolumn{4}{|l|}{ Sex } \\
\hline Males & $11(68.8)$ & $15(93.8)$ & 0.172 \\
\hline HLA mismatching & & & 0.325 \\
\hline 1 & $8(50.0)$ & $8(50.0)$ & \\
\hline 2 & $4(25.0)$ & $7(43.8)$ & \\
\hline 3 & $4(25.0)$ & $1(6.2)$ & \\
\hline eGFR (mL/min) & $5.29(3.82)$ & $5.02(2.19)$ & 0.812 \\
\hline $\operatorname{Scr}(\mu \mathrm{mol} / \mathrm{L})$ & $\begin{array}{l}1215.19 \\
(498.34)\end{array}$ & $\begin{array}{l}1208.50 \\
(321.40)\end{array}$ & 0.964 \\
\hline Urea (mmol/L) & $\begin{array}{l}23.93 \\
(15.17,36.56)\end{array}$ & $\begin{array}{l}20.94 \\
(16.88,25.31)\end{array}$ & 0.468 \\
\hline Urine protein $(q / L)^{1}$ & $1.25(1.00,3.00)$ & $3.00(2.00,3.00)$ & 0.201 \\
\hline Urinary RBC (count $/ \mu \mathrm{L})^{1}$ & $6.00(2.00,26.00)$ & $66.00(5.00,119.00)$ & $0.041 *$ \\
\hline Urinary WBC $(\text { count } / \mu \mathrm{L})^{1}$ & $8.00(3.00,38.00)$ & $11.00(4.00,23.00)$ & 0.747 \\
\hline Percentage of LN (\%) & $25.86(5.83)$ & $23.17(6.44)$ & 0.225 \\
\hline $\mathrm{LN}$ count $\left(10^{9} / \mathrm{L}\right)$ & $1.58(0.42)$ & $1.42(0.36)$ & 0.269 \\
\hline CD19 (\%) & $12.32(4.62)$ & $11.12(5.16)$ & 0.494 \\
\hline CD3 (\%) & $73.66(9.09)$ & $71.01(10.91)$ & 0.462 \\
\hline CD34 (\%) & $39.77(8.01)$ & $41.27(8.39)$ & 0.609 \\
\hline $\operatorname{CD} 38(\%)^{1}$ & $30.94(9.38)$ & $26.73(7.28)$ & 0.172 \\
\hline NK (\%) & $7.20(6.00,10.67)$ & $7(5.04,8.37)$ & 0.445 \\
\hline Follow-up duration (months) & $23.87(18.68,33.03)$ & $30.07(19.68,33.50)$ & 0.468 \\
\hline Age of donors & $45.56(12.98)$ & $50.56(6.85)$ & 0.183 \\
\hline Male gender of donors & $8(50.0 \%)$ & $5(31.3 \%)$ & 0.473 \\
\hline Creatinine of donors & $71.06(8.96)$ & $77.69(9.97)$ & 0.057 \\
\hline
\end{tabular}

eGFR, estimated glomerular filtration rate; Scr, serum creatinine; RBC, red blood cell; WBC, white blood cell; LN, lymphocytes; NK, natural killer

Continuous data were presented as mean (standard deviation) or median (interquartile range) and tested by the independent t-test or Mann-Whitney U test.

HLA mismatching was expressed as n (\%) and tested by Fisher's exact test.

*Indicates significant difference between the two groups, $P<0.05$.

${ }^{1}$ Some missing data were found. 
groups $(P<0.003)$. A significantly higher $\mathrm{LN}$ count was found at 3 months as well as 6 months as compared to day $7(P<0.003)$. Conversely, the proportion of CD19 cells increased, peaking at day 7 and then decreased gradually. The proportion of CD3 cells dropped at the same time and then fluctuated between $69 \%$ and $78 \%$ thereafter. The lowest percentages of CD34 and CD38 were detected at day 7; they increased at 1 month and were sustained thereafter. At 1 month, the CD34 percentage was significantly lower than the baseline value $(P<0.003)$. Finally, a significant reduction in the proportion of $\mathrm{NK}$ cells was found at day $7(P<0.003)$, and the values detected at other time points were similar with those observed at baseline (Table 3 ).

\section{Difference in serum creatinine and eGFR}

As shown in Figure 2A, the level of serum creatinine in both groups dropped rapidly after the surgery (Experimental group: 139.2 $\pm 29.4 \mu \mathrm{mol} / \mathrm{L}$; Control group: $183.6 \pm 198.7 \mu \mathrm{mol} / \mathrm{L})$ and was maintained thereafter. In contrast, the eGFR increased rapidly at day 7 (Experimental group: $57.5 \pm 15.2 \mathrm{~mL} / \mathrm{min}$; Control group: $65.4 \pm 33.2 \mathrm{~mL} / \mathrm{min}$ ) and plateaued through 24 months (Experimental group: $81.0 \pm 6.1 \mathrm{~mL} / \mathrm{min}$; Control group: $73.1 \pm 14.8 \mathrm{~mL} / \mathrm{min}$ ) (Figure $2 \mathrm{~B}$ ). There was no significant difference between the two groups in both serum creatinine $(P=0.698)$ and eGFR $(P=0.408)$.

\section{Adverse effects}

The percentage of patients with adverse events (AE) in the two groups was similar $(P=0.476)$. As shown in Table 4, lung infection (10 cases) was the most common AE. Other AEs included acute rejection (3 cases in the control group), liver dysfunction (2 cases), anemia (2 cases), perirenal hematoma ( 1 case), incomplete intestinal obstruction (1 case), diabetes ( 1 case) and fever (1 case).

\section{Chimerism}

The peripheral chimerism of the donor leukocytes was measured at 1, 36,12 , and 24 months. No chimerism was detected in any patient.

\section{Trough concentration of tacrolimus}

The trough concentration of tacrolimus was measured from Day 7. Patients treated with low-dose tacrolimus + MSCs had significantly lower trough levels than those who received a standard dose of tacrolimus $(P$ $<0.05$; Figure S1).

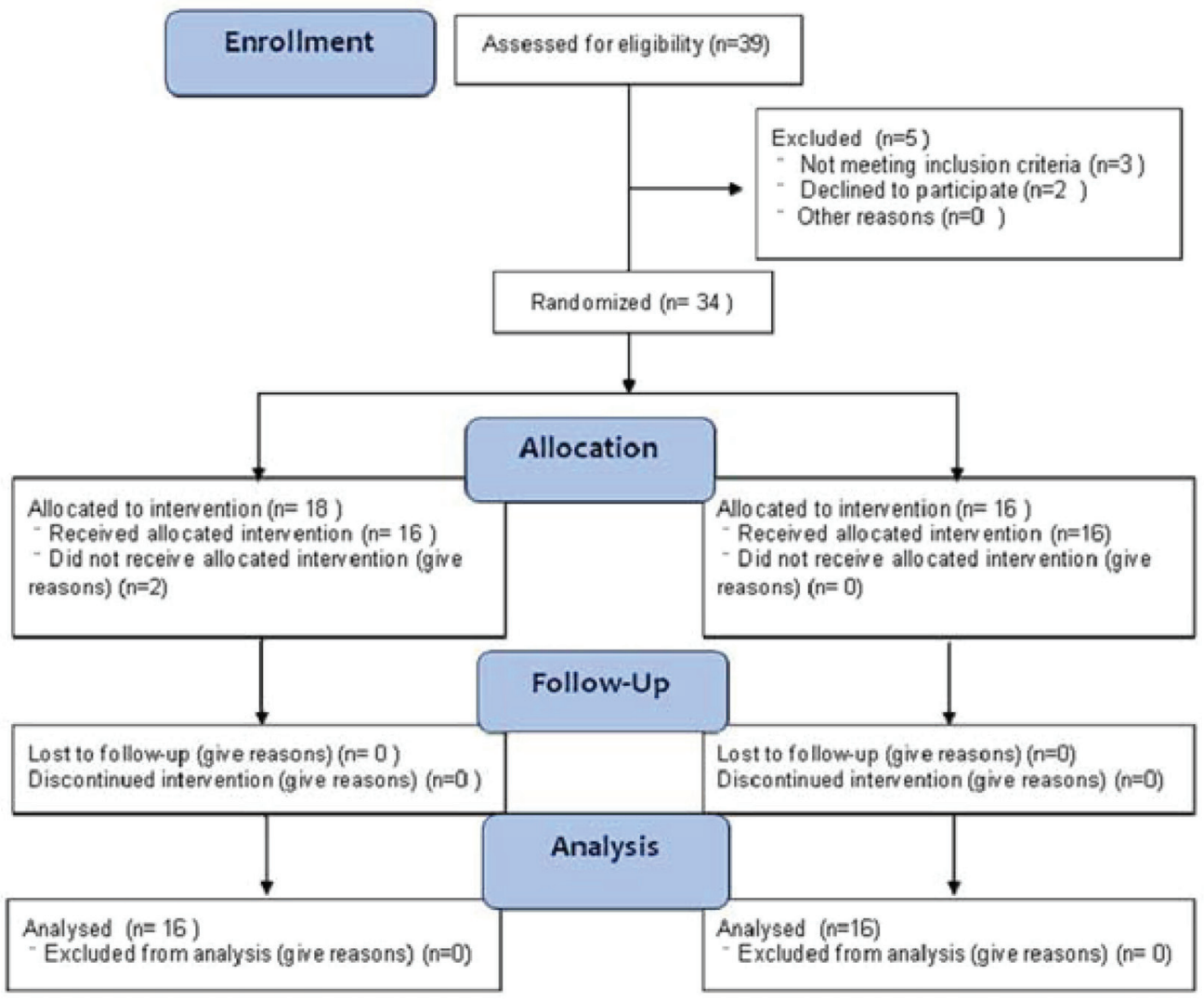

Figure 1: Patient inclusion into the study. 
Table 2: Comparisons of urea, urine protein, urinary RBC, urinary WBC, 24-h urine protein, and Ccr between the control $(n=16)$ and experimental $(n=16)$ groups

\begin{tabular}{|c|c|c|c|c|c|c|c|c|}
\hline & Group & Baseline & 7 days & $1 \mathrm{M}$ & $3 \mathrm{M}$ & $6 \mathrm{M}$ & $12 \mathrm{M}$ & $24 \mathrm{M}$ \\
\hline \multirow[t]{2}{*}{$\begin{array}{l}\begin{array}{l}\text { Urea } \\
(\mathrm{mmol} / \mathrm{L})^{1}\end{array} \\
\end{array}$} & Control & $\begin{array}{l}27.23 \\
(12.75)\end{array}$ & $13.96(10.38)^{\dagger}$ & $\begin{array}{l}9.83 \\
(7.63)^{\dagger}\end{array}$ & $6.58(1.94)^{\dagger, \S}$ & $6.25(1.39)^{\dagger, \S}$ & $\begin{array}{l}5.96 \\
(1.46)^{\dagger, \S}\end{array}$ & $\begin{array}{l}6.59 \\
(2.07)^{\dagger, \S}\end{array}$ \\
\hline & Experimental & $\begin{array}{l}22.54 \\
(9.34)\end{array}$ & $13.25(5.19)^{\dagger}$ & $\begin{array}{l}8.5 \\
(3.07)^{\dagger}\end{array}$ & $6.24(1.54)^{\dagger, \S}$ & $6.67(1.89)^{\dagger, \S}$ & $\begin{array}{l}6.07 \\
(1.76)^{\dagger, \S}\end{array}$ & $\begin{array}{l}5.71 \\
(1.75)^{\dagger, \S}\end{array}$ \\
\hline \multirow{2}{*}{$\begin{array}{l}\text { Urine protein } \\
(\mathrm{q} / 1)^{2}\end{array}$} & Control & $\begin{array}{l}1.25(1, \\
3)\end{array}$ & $\begin{array}{l}0.3 \\
0.85)^{\dagger} \quad(0.15\end{array}$ & $0(0,0)^{\dagger, \S}$ & $0(0,0)^{\dagger, \S}$ & $0(0,0.1)^{\dagger, \S}$ & $0(0,0)^{\dagger, \S}$ & $\begin{array}{ll}0 & (0, \\
0)^{\dagger, \S} & \\
\end{array}$ \\
\hline & Experimental & $3(2,3)$ & $\begin{array}{l}0.25 \\
0.35)^{\dagger} \quad(0.1\end{array}$ & $\begin{array}{l}0 \\
0.2)^{\dagger, \S}(0,\end{array}$ & $0(0,0)^{\dagger, \S}$ & $0(0,0)^{\dagger, \S}$ & $0(0,0)^{\dagger, \S}$ & $\begin{array}{l}0 \quad(0, \\
0)^{\dagger, \S} \quad\end{array}$ \\
\hline \multirow{2}{*}{$\begin{array}{l}\text { Urinary } \mathrm{RBC} \\
(\text { count } / \mu \mathrm{L})^{2}\end{array}$} & Control & $\begin{array}{l}6 \\
26)\end{array}$ & 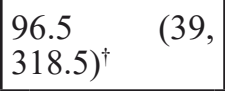 & \begin{tabular}{|l|}
$1.5(0.5$ \\
$5.5)^{\dagger, \S}$ \\
\end{tabular} & $0.2(0,2)^{\dagger, \S}$ & $1(0,2)^{\dagger, \S}$ & $0(0,7)^{\dagger, \S}$ & $\begin{array}{l}1 \\
2)^{\dagger, \S} \quad(0,\end{array}$ \\
\hline & Experimental & $\begin{array}{l}66 \\
119)\end{array}$ & $80.5(44,590)^{\dagger}$ & $\begin{array}{l}3 \quad(1.2, \\
7.5)^{\dagger, \S}\end{array}$ & $0(0,3.5)^{\dagger, \S}$ & $0.2(0,2.5)^{\dagger, \S}$ & $\begin{array}{l}0 \\
2.5)^{\dagger, \S} \quad(0,\end{array}$ & $\begin{array}{ll}0.5 & (0, \\
6)^{\dagger, \S} & \end{array}$ \\
\hline \multirow{2}{*}{$\begin{array}{l}\text { Urinary WBC } \\
(\text { count } / \mu \mathrm{L})^{2}\end{array}$} & Control & $\begin{array}{l}8 \\
(3,38)\end{array}$ & $\begin{array}{l}12 \\
(7.5,38)\end{array}$ & \begin{tabular}{|l|}
4.5 \\
$(2.5$ \\
$13.5)^{\S}$ \\
\end{tabular} & $\begin{array}{l}0.83 \\
(0,2)^{\dagger, \S, \emptyset}\end{array}$ & $\begin{array}{l}1.5 \\
(0,2.5)^{\dagger, \S, \uparrow}\end{array}$ & $\begin{array}{l}0 \\
(0,1.5)^{\dagger, \S, \uparrow}\end{array}$ & $\begin{array}{l}0 \\
(0, \\
0.66)^{\dagger, \S, \emptyset}\end{array}$ \\
\hline & Experimental & $\begin{array}{l}11 \quad 4, \\
23)\end{array}$ & $13(5.5,17.5)$ & $5(2,10)^{\S}$ & $0.93(0,2)^{\dagger, \S, \uparrow}$ & $0(0,1.5)^{\dagger, \S, \uparrow}$ & 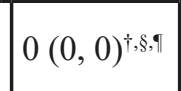 & $\begin{array}{l}0 \quad(0, \\
1)^{\dagger, \S, \emptyset}\end{array}$ \\
\hline \multirow{2}{*}{$\begin{array}{l}\text { 24-h urine } \\
\text { protein }(q / L)^{1}\end{array}$} & Control & ND & ND & $\begin{array}{l}216.28 \\
(158.73) \\
\end{array}$ & $176.86(69.73)$ & $\begin{array}{l}136.71 \\
(43.54) \\
\end{array}$ & $\begin{array}{l}144.11 \\
(49.49) \\
\end{array}$ & ND \\
\hline & Experimental & ND & ND & $\begin{array}{l}171.26 \\
(84.43)\end{array}$ & $171.36(134.51)$ & $\begin{array}{l}173.58 \\
(179.37)\end{array}$ & $\begin{array}{l}125.75 \\
(75.11)\end{array}$ & ND \\
\hline \multirow{2}{*}{$\operatorname{Ccr}(\mathrm{ml} / \mathrm{L})^{2}$} & Control & ND & ND & $\begin{array}{l}82.67 \\
(51.25 \\
92.44) \\
\end{array}$ & $\begin{array}{l}69.29 \\
86.18)\end{array}$ & $\begin{array}{l}74.02 \\
80.86)\end{array}(67.26$ & \begin{tabular}{|l}
77.9 \\
$(66.02$ \\
$91.75)$ \\
\end{tabular} & ND \\
\hline & Experimental & ND & ND & $\begin{array}{l}63.54 \\
(55.35 \\
78.27) \\
\end{array}$ & $\begin{array}{l}66.79 \\
75.54)\end{array}$ & $\begin{array}{l}68.75 \\
80.52)\end{array}(63.65$ & \begin{tabular}{|l|}
68.25 \\
$(61.6$, \\
$87.09)$ \\
\end{tabular} & ND \\
\hline
\end{tabular}

RBC, red blood cell; WBC, white blood cell; ND, not determined; Ccr, creatinine clearance rate.

${ }^{1}$ Data were presented as mean (standard deviation) and tested using the linear mixed model.

${ }^{2}$ Data were presented as median (interquartile range) and tested using the Friedman test for time effect and Mann-Whitney

$\mathrm{U}$ test for group effect.

$\dagger$ significantly different from the baseline value, $P<0.003$.

$\S$ significantly different from Day $7, P<0.003$.

๑ significantly different from 1 month, $P<0.003$.

\section{DISCUSSION}

In this pilot study, we compared the outcomes of allograft renal transplant patients treated with low-dose tacrolimus in combination with MSCs with those treated with a standard dosage of tacrolimus. There was no significant difference in acute rejection and graft survival, serum creatinine and eGFR. Although most clinical parameters were similar between the groups, CD38 and NK cells were higher in the control group, suggesting an increased response to cellular stress possibly caused by tacrolimus. Both groups showed similar immune response to donor alloantigens in MLR experiments and the analogous characteristics of T-cell subpopulations measured by flow cytometry.

In addition to its immunosuppressive effects [18], tacrolimus can also cause cytotoxicity [19], including interstitial fibrosis and tubular atrophy, resulting in late dysfunction of transplanted kidneys [20]. Although lower doses of tacrolimus are more desirable to prevent cytotoxicity in renal transplant patients. But, they are associated with a greater risk of acute rejection [21, 22]. Richards et al. [23] recently reported that a tacrolimus trough concentration of $\geq 8 \mathrm{ng} / \mathrm{mL}$ by day 5 was required to prevent biopsy-proven acute rejection. Therefore, other adjunctive therapeutic strategies are required to ensure the safety and efficacy of low-dose tacrolimus. MCSs appear to be a fitting therapeutic target for that purpose, especially given their specific immunosuppressive and immune evasive properties [24].

Autogenic, allogenic, and third party MSCs suppress lymphocyte [15] and leukocyte [12] proliferation. In vivo studies have also illustrated their immunosuppressive capacity as intravenous administration of donor MSCs 
Table 3: Comparisons of percentage of lymphocytes, CD19, CD3, CD34, CD38, and natural killer cell between the control $(n=16)$ and experimental $(n=16)$ groups

\begin{tabular}{|c|c|c|c|c|c|c|c|c|}
\hline \multirow{3}{*}{$\begin{array}{l}\text { Variables } \\
\begin{array}{l}\text { Percentage } \\
\text { of LN }(\%)^{1}\end{array}\end{array}$} & \multirow{2}{*}{$\begin{array}{l}\text { Group } \\
\text { Control }\end{array}$} & \multirow{2}{*}{$\begin{array}{l}\text { Baseline } \\
25.86(5.83)\end{array}$} & \multicolumn{2}{|l|}{7 days } & \begin{tabular}{|l|l}
$3 \mathrm{M}$ & $6 \mathrm{M}$
\end{tabular} & \multicolumn{2}{|l|}{$12 \mathrm{M}$} & \multirow{2}{*}{$\begin{array}{l}24 \mathrm{M} \\
22.66 \\
(5.20)^{\S}\end{array}$} \\
\hline & & & $10.87(5.49)^{\dagger}$ & $\begin{array}{l}15.91 \\
(8.01)^{\dagger}\end{array}$ & $19.07(6.31)$ & $20.24(6.79)$ & \begin{tabular}{|l|}
17.65 \\
$(5.54)$
\end{tabular} & \\
\hline & Experimental & 23.17 (6.44) & $16.23(5.88)^{\dagger}$ & $\begin{array}{l}18.68 \\
(8.33)^{\dagger}\end{array}$ & $17.91(7.43)$ & $18.76(5.21)$ & $\begin{array}{l}21.33 \\
(7.01) \\
\end{array}$ & $\begin{array}{l}25.02 \\
(13.21)^{\S}\end{array}$ \\
\hline \multirow{2}{*}{$\begin{array}{l}\mathrm{LN} \text { count } \\
\left(10^{9} / \mathrm{L}\right)^{2}\end{array}$} & Control & $\begin{array}{l}1.64 \\
1.81)\end{array}$ & $\begin{array}{l}1.00 \\
1.27)\end{array}$ & $\begin{array}{l}1.21(1.00, \\
1.71)\end{array}$ & $\begin{array}{l}1.72 \\
16.59)^{\S}\end{array}$ & $\begin{array}{l}1.40 \\
10.35)^{\S}\end{array}$ & \begin{tabular}{|l|}
1.15 \\
$(1.00$, \\
$1.40)$ \\
\end{tabular} & $\begin{array}{l}1.38 \\
(1.36 \\
1.80) \\
\end{array}$ \\
\hline & Experimental & $\begin{array}{l}1.42 \\
1.68)\end{array}$ & $\begin{array}{l}1.41 \\
1.72)\end{array}$ & $\begin{array}{l}1.41 \\
1.72)\end{array}$ & $\begin{array}{l}1.46 \\
13.92)^{\S}\end{array}$ & $\begin{array}{l}1.56 \\
8.44)^{\S}\end{array}(1.15$ & \begin{tabular}{|l|}
1.27 \\
$(1.13$ \\
$2.21)$ \\
\end{tabular} & \begin{tabular}{|l|}
1.47 \\
$(1.35$ \\
$3.35)$ \\
\end{tabular} \\
\hline \multirow{2}{*}{ CD19 $(\%)^{1}$} & Control & $12.32(4.62)$ & $\begin{array}{l}39.29 \\
(17.13)^{\dagger}\end{array}$ & $\mid \begin{array}{l}17.7 \\
(11.20)^{\S}\end{array}$ & $15.57(8.71)^{\S}$ & $12.58(6.73)^{\S}$ & $\begin{array}{l}11 \\
(4.19)^{\S}\end{array}$ & $\begin{array}{l}12.18 \\
(6.19)^{\S}\end{array}$ \\
\hline & Experimental & $11.12(5.16)$ & $\begin{array}{l}32.54 \\
(19.55)^{\dagger}\end{array}$ & $\begin{array}{l}20.13 \\
(10.34)^{\S}\end{array}$ & $17.88(12.58)^{\S}$ & $12.57(8.46)^{\S}$ & $\begin{array}{l}11.18 \\
(5.48)^{\S}\end{array}$ & $\begin{array}{l}13.79 \\
(6.67)^{\S}\end{array}$ \\
\hline \multirow{2}{*}{ CD3 $(\%)^{1}$} & Control & $73.66(9.09)$ & $\begin{array}{l}47.88 \\
(18.57)^{\dagger}\end{array}$ & $\begin{array}{l}69.2 \\
(11.62)^{\S}\end{array}$ & $74.11(7.75)^{\S}$ & $77.1(11.20)^{\S}$ & $\begin{array}{l}78.24 \\
(7.19)^{\S}\end{array}$ & $\begin{array}{l}73.38 \\
(9.46)^{\S}\end{array}$ \\
\hline & Experimental & $71.01(10.91)$ & $\begin{array}{l}53.02 \\
(20.61)^{\dagger}\end{array}$ & $\begin{array}{l}71.28 \\
(11.90)^{\S}\end{array}$ & $72.75(11.58)^{\S}$ & \begin{tabular}{|l|}
72.99 \\
$(15.06)^{\S}$
\end{tabular} & \begin{tabular}{|l}
75.03 \\
$(9.32)^{\S}$
\end{tabular} & $\begin{array}{l}71.91 \\
(9.96)^{\S}\end{array}$ \\
\hline \multirow[t]{2}{*}{ CD34 $(\%)^{1}$} & Control & $39.77(8.01)$ & $21.95(9.16)^{\dagger}$ & $\begin{array}{l}31.62 \\
(8.94)^{\dagger}\end{array}$ & $30.76(7.88)^{\dagger}$ & $\begin{array}{l}32.66 \\
(11.10)^{\dagger}\end{array}$ & $\begin{array}{l}32.68 \\
(9.98)^{\dagger}\end{array}$ & $\begin{array}{l}30.29 \\
(7.89)^{\dagger}\end{array}$ \\
\hline & Experimental & $41.27(8.39)$ & $\begin{array}{l}27.97 \\
(12.28)^{\dagger}\end{array}$ & $\begin{array}{l}30.99 \\
(11.15)^{\dagger}\end{array}$ & $31.25(9.74)^{\dagger}$ & $29.86(8.83)^{\dagger}$ & $\begin{array}{l}31.37 \\
(6.25)^{\dagger}\end{array}$ & $\begin{array}{l}30.08 \\
(7.84)^{\dagger}\end{array}$ \\
\hline \multirow[t]{2}{*}{ CD38 $(\%)^{1}$} & Control & $30.94(9.38)$ & $22.6(9.26)$ & $\begin{array}{l}37.44 \\
(10.36)^{\S}\end{array}$ & $36.48(8.86)^{\S}$ & $35.1(9.50)^{\S}$ & \begin{tabular}{|l}
35.63 \\
$(12.07)^{\S}$
\end{tabular} & $\begin{array}{l}33.06 \\
(6.20)\end{array}$ \\
\hline & Experimental & $26.73(7.28)$ & $23.71(6.6)$ & $32.22(8)^{\S}$ & $31.44(7.68)^{\S}$ & \begin{tabular}{|l}
33.55 \\
$(10.49)^{\S}$
\end{tabular} & \begin{tabular}{|l}
32.92 \\
$(8.29)^{\S}$
\end{tabular} & $\begin{array}{l}28.99 \\
(4.68)\end{array}$ \\
\hline \multirow[t]{2}{*}{$\begin{array}{l}\text { Natural } \\
\text { killer cell } \\
(\%)^{1}\end{array}$} & Control & $8.06(3.01)$ & $4.46(2.56)^{\dagger}$ & $5.51(3.66)$ & $6.65(3.43)$ & $5.92(4.42)$ & $\begin{array}{l}5.86 \\
(3.85)\end{array}$ & $\begin{array}{l}7.83 \\
(4.64)\end{array}$ \\
\hline & Experimental & $7.13(3.03)$ & $2.93(2.41)^{\dagger}$ & 4.37 (3.41) & $4.76(3.09)$ & $6.02(4.1)$ & $\begin{array}{l}4.94 \\
(2.68)\end{array}$ & $\begin{array}{l}6.55 \\
(4.74)\end{array}$ \\
\hline
\end{tabular}

LN, lymphocytes

${ }^{1}$ Data were presented as mean (standard deviation) and tested using thr linear mixed model.

${ }^{2}$ Data were presented as median (interquartile range) and tested using the Friedman test for time effect and Mann-Whitney

$\mathrm{U}$ test for group effect.

$\uparrow$ Significantly different from the baseline value, $P<0.003$.

$\S$ Significantly different from Day $7, P<0.003$.

effectively prolonged graft survival in animal models [13, 15]. Specifically, injection of in vitro-amplified MSCs into a recipient baboon followed by allogeneic skin graft transplantation showed a delay in transplant rejection and an extension of the graft survival time [12]. Donorderived MSCs have also induced the long-term acceptance of solid organ allografts [25]. However, the mechanism by which MSCs impart their immunosuppressive effects is not fully known. In vitro analyses using co-cultures with transwell assays showed that cell-cell contact was not necessary for suppression [26]. Specifically, MSCs inhibited autologous $\mathrm{T}$ cell proliferation through secretion of transforming growth factor- $\beta$ (TGF- $\beta$ ) and hepatocyte growth factor (HGF) [26]. The low levels of MHC class I and lack of MHC class II, B7-1, B7-2, or CD40 expression by MSCs gives further support that they illicit their immunosuppressive functions through a paracrine factors [24]. Furthermore, Le Blanc et al. [10] showed that the MSC-mediated immunosuppression was dose-dependent and not MHC-restricted, suggesting an important role for MSCs in clinical practice. Although further mechanistic studies are necessary to fully determine the role of MSCs in allo-rejection, their use in clinical trials is increasing [24].

Perico et al. [27] showed that autologous MSCs prevented acute rejection in two renal transplant patients 
Table 4: Comparison of the adverse effects between the control $(n=16)$ and experimental $(n=16)$ groups

\begin{tabular}{|l|l|l|l|}
\hline \hline & $\begin{array}{l}\text { Control } \\
(\boldsymbol{n}=\mathbf{1 6})\end{array}$ & $\begin{array}{l}\text { Experimental } \\
(\boldsymbol{n}=\mathbf{1 6})\end{array}$ & $\boldsymbol{P}$-value \\
\hline Acute rejection & $3(18.8)$ & $0(0.0)$ & 0.226 \\
\hline Diabetes & $0(0.0)$ & $1(6.3)$ & 1.000 \\
\hline Hyperlipidemia & $3(18.8)$ & $1(6.3)$ & 0.600 \\
\hline Anemia & $0(0.0)$ & $2(12.5)$ & 0.484 \\
\hline Lung infection & $7(43.8)$ & $3(18.8)$ & 0.252 \\
\hline Liver dysfunction & $1(6.3)$ & $1(6.3)$ & 1.000 \\
\hline Incomplete intestinal obstruction & $0(0.0)$ & $1(6.3)$ & 1.000 \\
\hline Fever & $1(6.3)$ & $0(0.0)$ & 1.000 \\
\hline Perirenal hematoma & $1(6.3)$ & $0(0.0)$ & 1.000 \\
\hline
\end{tabular}

Data were presented as count and percentage and tested using Chi-square test.

(A)

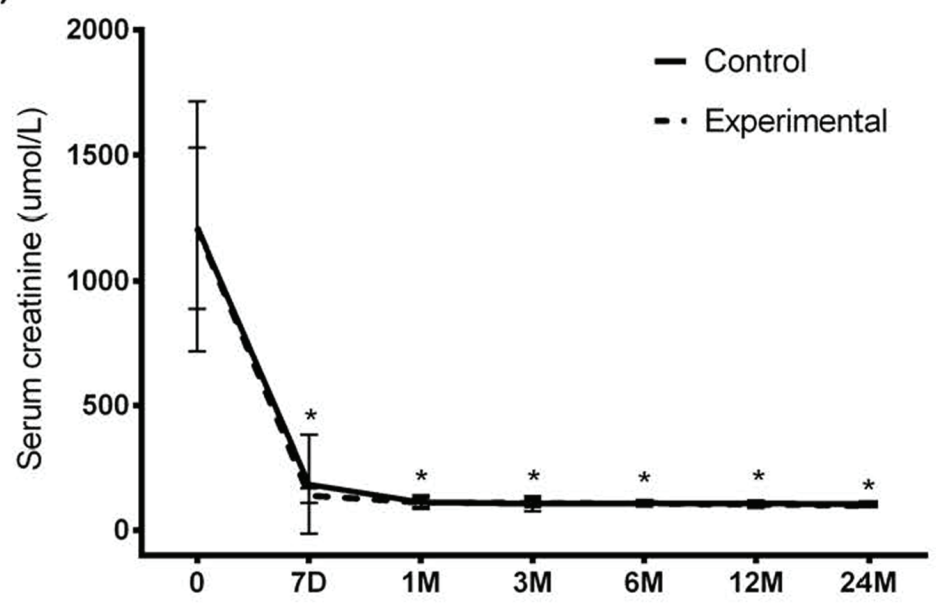

(B)

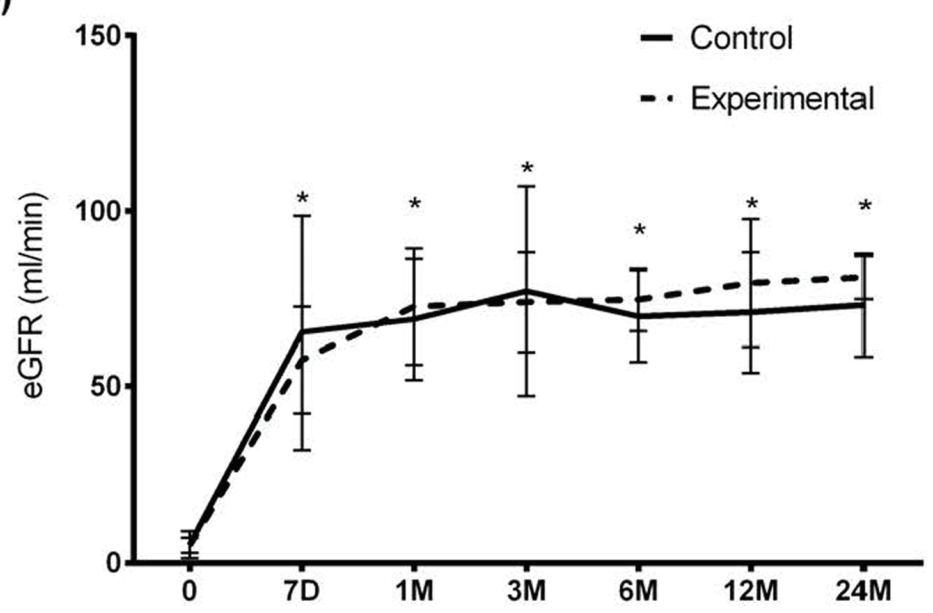

Figure 2: Serum creatinine and eGFR throughout the study period. A. Serum creatinine and B. eGFR were measured in the experimental and control groups. Data were presented as mean (standard deviation). Linear mixed model revealed a significant time effect $(P<0.001)$. Asterisk indicates significantly different from baseline, $P<0.003$. 
who received kidneys from living-related donors and received maintenance immunosuppression with cyclosporine and mycophenolate mofetil. In a phase I clinical study that included six renal transplant patients, Reinders et al. [28] found that autologous bone marrowderived MSCs provided systemic immunosuppression and was safe at $1-2 \times 10^{6}$ cells per kilogram of body weight. Reinders' group has subsequently initiated a phase II study that will include 70 renal allograft recipients to examine if MSCs with everolimus, a mammalian target of rapamycin (mTOR) inhibitor, can facilitate tacrolimus withdrawal and decrease fibrosis as well as opportunistic infection [29]. Similarly, Tan et al. [16] showed the efficacy of autologous MSCs even at a $20 \%$ reduction in the dosage of calcineurin inhibitors.

We chose the combination of low-dose tacrolimus with MSCs rather than a tacrolimus withdrawal due to the toxicity of MSCs observed with high doses of tacrolimus reported by Hoogduijn et al. [30]. Furthermore, increased immunosuppression by MSCs was observed following preincubation with tacrolimus, which is suggestive of their additive potential [30]. Our results indicate that donor-derived MSCs combined with low-dose tacrolimus has similar efficacy to standard immunosuppression following living-related renal transplantation. Given that a randomized trial of 74 patients showed a significant reduction in acute GVHD with tacrolimus and sirolimus, a mTOR inhibitor, compared with tacrolimus and methotrexate [31], further studies will analyze the effect of including MSCs with tacrolimus and sirolimus.

Although previous studies have shown immunosuppressive activities for MSCs and suppression of graft-versus-host disease [32,33], which is in agreement with the results of the present study, further studies are necessary to define the exact protocol for the culture, expansion, and administration of MSCs [34]. In rats, MSCs injected into the renal artery were retained in the glomeruli, lowering the frequency of glomerulonephritis and preventing acute cellular rejection $[35,36]$. However, our studies are the first to show that the administration of MSCs by intra-arterial injection is feasible and safe as was evidenced by the absence of embolism, thrombosis, infection, or any other complications, within 12 months of transplantation. We hypothesize that direct injection of MSCs into the renal artery may locally depress the inflammatory response and, therefore nonspecifically protect the graft.

Donor leukocytes can be detected many years after solid organ transplantation in recipients with longterm graft survival and who were able to safely reduce or discontinue immunosuppression therapy [37]. In the present study, chimerism was undetectable at 3 and 12 months post-transplantation. In addition, recent studies of transplant patients who maintain stable kidney graft function in the absence of immunosuppression drugs showed that these patients have more peripheral B cells
$[38,39]$. In the present study, patients in the experimental group had more peripheral B cells than those in the control group at 3 months. However, further research is required to determine whether the variation of peripheral B cells alters long-term graft function.

In addition to the small study sample, the present study is limited in the lack of mechanistic data. In addition, although the immunosuppressive properties of MSCs have been well-established, MSC are still immunogenic to a certain extent [24], which may limit their clinical application. Finally, MSC therapy may also be limited in that their effects do not persist following infusion, necessitating further applications.

In conclusion, immunosuppression can be maintained after allograft renal transplantation with low-dose tacrolimus ( $\sim 60 \%$ of the standard dosage) in combination with donor-derived MSCs, which may decrease the nephrotoxicity associated with many immunosuppressants. Further research is needed to determine the minimum effective dosage of tacrolimus when used in combination with MSCs. Further mechanistic analyses of the combination therapy are also required. The findings could be beneficial in ensuring long-term graft survival after renal transplantation.

\section{MATERIALS AND METHODS}

\section{Patient characteristics}

The kidney transplantations were performed from September 2009 to January 2011. As shown in Figure 1, 39 patients were assessed for eligibility. Three did not meet the inclusion criteria, and two declined to participate. Therefore, 34 uremia patients were assigned to receive either experimental or control intervention, but two patients did not. The remaining 32 patients were divided into an experimental group (MSC group, $n=16$ ) and a control group (non-MSC group, $n=16$ ).

\section{Study design}

The materials and methods of this study are similar to those of our pilot study. They were outlined in our previous publication and are restated here in their entirety, except for changes that are pertinent to the follow-up study [40]. Donors and recipients undergoing living-related kidney transplantation procedures in the Second Affiliated Hospital of Guangzhou Medical University were considered for enrollment in this prospective, nonrandomized pilot study. Donor selection complied with the 2004 Amsterdam Forum Guidelines [41] and the 2007 Chinese "Regulation on Human Organ Transplantation" (Order of the State Council No. 491) [17]. All candidates met the following inclusion 
criteria: (a) patients were undergoing primary kidney transplantation; (b) donors and recipients were 18 to 60 $\mathrm{y}$ of age and $\mathrm{ABO}$ compatible; (c) the primary kidney disease was chronic glomerulonephritis; (d) tacrolimus, rather than cyclosporine $\mathrm{A}$, was used as the maintenance immunosuppressant; and (e) complement-dependent cytotoxicity examination and panel reactive antibody examination were negative (G10\%) before kidney transplantation.

Potential enrollees were excluded if (a) kidney transplantation was secondary, multiple, or combined with the transplantation of other allograft organs; (b) recipients had systemic or active infections; (c) recipients had a history of severe cardiovascular or pulmonary dysfunction, malignancy, liver dysfunction, and chronic enteritis; (d) recipients had diabetes mellitus or other glycometabolic disorders; and (e) tacrolimus had to be replaced with another immunosuppressant(s) after kidney transplantation. The participants were consecutive candidates for transplantation that were eligible for the study and were assigned into the experimental group or the control group at their choice.

As induction therapy, all enrolled recipients were prescribed Cytoxan $(200 \mathrm{mg} /$ day $)$ and methylprednisolone (750, 500, and $250 \mathrm{mg}$ /day) from days 0 to 3 . Beginning on day 4 , patients in the control group received a standard dose of tacrolimus (0.07-0.08 $\mathrm{mg} / \mathrm{kg} /$ day), whereas patients in the experimental group received a low dose of tacrolimus $(0.04-0.05 \mathrm{mg} / \mathrm{kg} /$ day) and two infusions of MSCs. The first infusion of MSCs $\left(5 \times 10^{6}\right.$ cells) was delivered directly into the renal allograft artery at the time of kidney transplantation. Briefly, a Gibson's incision was made at the lower abdomen, and the internal iliac artery and external iliac vein were exposed. End-to-end anastomosis was performed between the renal and internal iliac arteries, and end-to-side anastomosis was performed between the renal and the external iliac veins. Prior to finishing the last stitch during the arterial anastomosis, a $22 \mathrm{~F}$ catheter needle was inserted from the anastomosis site along the direction of blood flow, fixed, and connected to a sterile transfusion apparatus. When restoring the blood flow to the transplanted kidney, $10 \mathrm{~mL}$ of saline-diluted MSCs $\left(5 \times 10^{6}\right)$ were quickly infused (within $\left.2 \mathrm{~min}\right)$ using a pressurizer. The catheter was removed after infusion, and the gap was sutured. Inverted mastoid-shaped anastomosis was carried out between the ureter and the bladder. After one month, the second infusion $\left(2 \times 10^{6}\right.$ cells $/ \mathrm{kg}$ diluted in $50 \mathrm{~mL}$ normal saline) was administered intravenously over $20 \mathrm{~min}$. Mycophenolate mofetil (1 g/day) and prednisone were also prescribed to patients in both groups. An oral administration of prednisone was initiated at $30 \mathrm{mg} /$ day at day 4 after kidney transplantation and then tapered by $5 \mathrm{mg}$ every week to the maintenance dose of $15 \mathrm{mg}$ /day.

Patients were followed up for at least 2 y (the original 12 patients were followed up for up to $4 \mathrm{y}$ ) after kidney transplantation. The 2-y cumulative rates of acute rejection in both groups were compared. Acute rejection was diagnosed based on clinical manifestations. Serum creatinine was examined at baseline, and at 7 days as well as $1,3,6,12$ and 24 months after treatment.

This study was performed in accordance with the Declaration of Helsinki and was approved by the Ethical Committee of the Second Affiliated Hospital of Guangzhou Medical University. Written informed consent was obtained from all recipients and donors.

\section{MSC isolation and characterization}

MSC isolation and identification was undertaken at the Center for Stem Cell Biology and Tissue Engineering of Sun Yat-sen University. Briefly, approximately $50 \mathrm{~mL}$ of bone marrow aspirate from healthy adults was diluted in $100 \mathrm{~mL}$ of PBS after which separation medium (SigmaAldrich, St. Louis, MO, USA) was added at a ratio of $1: 2$ to form a clear interface. After centrifugation at 2000 rpm for $20 \mathrm{~min}$, the mononuclear cells were extracted, transferred to a new centrifuge tube, mixed with PBS $(1: 5, v: v)$, and centrifuged at $2000 \mathrm{rpm}$ for $10 \mathrm{~min}$. After the cells were washed with $10 \mathrm{~mL}$ PBS, the supernatant was removed, $4 \mathrm{~mL}$ of low-glucose medium (GIBCO-Life Technologies, Thermo Fisher Scientific, Inc. Waltham, MA, USA) was added, and the cells were cultured in a $37^{\circ} \mathrm{C}$ incubator. The low-glucose medium was changed once every three days. After approximately 10 days, cell colonies were formed, and $0.25 \%$ trypsin was used for cell dissociation. The cells were sub-cultured at a ratio of $1: 2$ until reaching a total of $10^{8}$ cells over five passages after which they were preserved in liquid nitrogen (see Figure S1A, SDC, http://links.lww.com/TP/A728).

Flow cytometry analysis of $1 \times 10^{5}$ cells (in $100 \mu \mathrm{L}$ ) incubated with $10 \mu \mathrm{L}$ of fluorophore-labeled antibodies $(1: 1000)$ revealed that the isolated cells expressed the surface markers, CD29, CD44, CD73, CD90, CD105, and CD166, but not the hematopoietic markers, CD45 and CD34 (see Figure S1B, SDC, http://links.lww.com/TP/ A728). All antibodies and isotype-matched controls were from eBioscience (San Diego, CA). Cells were acquired using a multicolor cytometer MoFlo Astrios (Beckman Coulter, Brea, CA, USA), and data were analyzed with CellQuest Pro software (Becton Dickinson, Franklin Lakes, NJ).

After the sixth passage, the multiple differentiation capacity of MSCs was confirmed by $0.5 \%$ oil red staining for adipogenic differentiation (see Figure S1C, SDC, http://links.lww.com/TP/A728) and 0.1\% alizarin red staining for osteogenic differentiation (see Figure S1D, SDC, http://links.lww.com/TP/A728) as described previously $[42,43]$. 


\section{Immune monitoring}

White blood cells were routinely counted before transplantation (day 0) and at 3, 6, and 12 months after transplantation. Immunophenotyping for characteristics of $\mathrm{T}$ lymphocytes and related subpopulations $\left(\mathrm{CD}^{+}{ }^{+} \mathrm{CD} 4^{+} \mathrm{CD} 8^{-}\right.$and $\left.\mathrm{CD}^{+} \mathrm{CD} 4{ }^{-} \mathrm{CD} 8^{+}\right)$, total $\mathrm{B}$ lymphocytes, and $\mathrm{NK}$ cells $\left(\mathrm{CD} 56^{+} \mathrm{CD} 3{ }^{-} \mathrm{NKG} 2 \mathrm{~A} / \mathrm{NKG} 2 \mathrm{D}\right)$ was performed using $100 \mu \mathrm{L}$ of whole blood with $20 \mu \mathrm{g}$ of antibody with a multicolor flow cytometry (all antibodies and isotype-matched controls were from eBioscience). Cells were acquired using a multicolor cytometer MoFlo Astrios (Beckman Coulter), and data were analyzed with CellQuest Pro software (Becton Dickinson).

\section{Mixed lymphocytes reaction (MLR)}

The one-way MLR was conducted to evaluate the recipients' response to donor alloantigen challenge. Peripheral blood mononucleated cells (PBMCs) were obtained (and frozen) from 12 recipients at day 0 and months 3, 6, and 12 and labeled with carboxyfluorescein diacetate, succinimidyl ester (Sigma-Aldrich, St. Louis, MO, USA). Aliquots of $1 \times 10^{5}$ recipient PBMCs were plated and stimulated with $1 \times 10^{5}$ donor PBMCs pretreated with mitomycin C (Sigma). Cultured cells were harvested after 6 days, and proliferation was measured by FACSCalibur flow cytometer (Becton Dickinson).

\section{Detection of chimerism}

Chimerism was assessed at 3 and 12 months. PCR co-amplification of 16 euchromosomal short-tandem repeat loci (D8S1179, D21S11, D7S820, CSF1PO, D3S1358, THO1, D13S317, D16S539, D2S1338, 19S433, vWA, TPOX, D18S51, D5S818, FGA, and AMEL) was performed in a fluorescence-based multiplex reaction using the AmpFLSTR Identifier kit (Applied Biosystems, Foster City, CA, USA). All loci were amplified using a GeneAmp PCR System 9600 (Applied Biosystems). The amplified products were detected by capillary electrophoresis using an ABI 3130XL DNA Genetic Analyzer (Applied Biosystems). Short-tandem repeat profiles were analyzed using GeneScan and Genotyper Analysis Software (Applied Biosystems).

\section{Determination of estimated glomerular filtration rate (eGFR)}

The eGFR (i.e., flow rate of filtered fluid through the kidney) was determined using a Discovery VH (GE Healthcare, LLC, Wauwatosa, WI, USA). eGFR was calculated using the follow formula: eGFR $(\mathrm{mL} / \mathrm{min} / 1.73$ $\left.\mathrm{m}^{2}\right)=186 \times(\text { creatinine }, \mathrm{mg} / \mathrm{dL})^{-1.154} \times(\text { age }, \mathrm{y})^{-0.203}(\times 0.742$ if female).

\section{Statistical analysis}

Normally distributed interval data were presented as mean (standard deviation, SD) and tested by independent t-tests. Median and inter-quartile ranges were calculated for interval data with skewed distributions, and MannWhitney $U$ tests were further applied to test the differences between control and experimental groups. Categorical variables were expressed as count (percentage) and tested using Chi-square tests; however, if there were more than $20 \%$ of cells with expected value less than five cells, Fisher's exact tests were applied instead. Linear mixed models encompassed fixed effects of time and group and were implemented for longitudinal data with normal distributions. If longitudinal data with skewed distributions existed, Friedman tests and Mann-Whitney $U$ tests were used instead to test the time effect and group effect, respectively. A two-tailed alpha level was set at 0.05 . The alpha level was adjusted to 0.003 when multiple comparisons were applied. Statistical analyses were assessed using SPSS software version 15.0 (SPSS Inc, Chicago, IL, USA).

\section{Authors' contributions}

Guang-hui Pan: conceptualization and design; drafting of the manuscript; critical revision of the manuscript; final approval of the manuscript; guarantor of the integrity of the entire study;,administrative, technical or material support; and supervision of the entire study.

Zheng Chen: acquisition of data, drafting of the manuscript, critical review of the manuscript, final approval of the manuscript, statistical analysis, definition of intellectual content, and supervision of the clinical and experimental studies.

$\mathrm{Lu} \mathrm{Xu}$ : acquisition of the data, analysis and interpretation of the data, critical review of the manuscript, final approval of the manuscript, statistical analysis, and literature search.

Jing-hui Zhu: analysis and interpretation of the data, critical review of the manuscript, final approval of the manuscript, and literature search.

Peng Xiang: acquisition of the data, analysis and interpretation of the data, critical review of the manuscript, final approval of the manuscript, statistical analysis, and experimental studies.

Jun-jie Ma: analysis and interpretation of the data; drafting of the manuscript; final approval of the manuscript; statistical analysis; and administrative, technical or material support.

Yan-wen Peng: acquisition of the data, critical review of the manuscript, final approval of the manuscript, literature search, and experimental studies. 
Guang-hui Li: analysis and interpretation of the data, drafting of the manuscript, final approval of the manuscript, literature search, and clinical studies.

Jia-li Fang: analysis and interpretation of the data, drafting of the manuscript, final approval of the manuscript, statistical analysis, definition of intellectual content, and clinical studies.

Yu-he Guo: acquisition of the data, analysis and interpretation of the data, drafting of the manuscript, final approval of the manuscript, and statistical analysis.

Lei Zhang: analysis and interpretation of the data, drafting of the manuscript, final approval of the manuscript, and clinical and experimental studies.

Long-shan Liu: acquisition of the data, drafting of the manuscript, final approval of the manuscript, and experimental studies.

\section{CONFLICTS OF INTEREST}

The authors declare that they have no competing interests.

\section{GRANT SUPPORT}

Science and Technology Planning Project of Guangdong Province, China(20100309), Science and Technology Planning Project of Guangdong Province, China (2014A020211027).

\section{REFERENCES}

1. Liu J, Farmer JD Jr, Lane WS, Friedman J, Weissman I, Schreiber SL. Calcineurin is a common target of cyclophilin-cyclosporin A and FKBP-FK506 complexes. Cell. 1991; 66: 807-815.

2. Starzl TE, Todo S, Fung J, Demetris AJ, Venkataramman R, Jain A. FK 506 for liver, kidney, and pancreas transplantation. Lancet. 1989; 2: 1000-1004.

3. Hardinger KL, Koch MJ, Brennan DC. Current and future immunosuppressive strategies in renal transplantation. Pharmacotherapy. 2004; 24: 1159-1176.

4. Nankivell BJ, Borrows RJ, Fung CL, O'Connell PJ, Chapman JR, Allen RD. Calcineurin inhibitor nephrotoxicity: longitudinal assessment by protocol histology. Transplantation. 2004; 78: 557-565.

5. Wu Q, Marescaux C, Wolff V, Jeung MY, Kessler R, Lauer V, Chen Y. Tacrolimus-associated posterior reversible encephalopathy syndrome after solid organ transplantation. Eur Neurol. 2010; 64: 169-177.

6. Ekberg H, Bernasconi C, Tedesco-Silva H, Vítko S, Hugo C, Demirbas A, Acevedo RR, Grinyó J, Frei U, Vanrenterghem Y, Daloze P, Halloran P. Calcineurin inhibitor minimization in the Symphony study: observational results 3 years after transplantation. Am J Transplant. 2009; 9: 1876-1885.

7. Deans RJ, Moseley AB. Mesenchymal stem cells: biology and potential clinical uses. Exp Hematol. 2000; 28: 875884.

8. Pittenger MF, Mackay AM, Beck SC, Jaiswal RK, Douglas R, Mosca JD, Moorman MA, Simonetti DW, Craig S, Marshak DR. Multilineage potential of adult human mesenchymal stem cells. Science. 1999; 284: 143-147.

9. Battiwalla M, Hematti P. Mesenchymal stem cells in hematopoietic stem cell transplantation. Cytotherapy. 2009; 11:503-515.

10. Le Blanc K, Rasmusson I, Sundberg B, Götherström C, Hassan M, Uzunel M, Uzunel M, Ringdén O. Treatment of severe acute graft-versus-host disease with third party haploidentical mesenchymal stem cells. Lancet. 2004; 363 : 1439-1441.

11. Weng JY, Du X, Geng SX, Peng YW, Wang Z, Lu ZS, Wu SJ, Luo CW, Guo R, Ling W, Deng CX, Liao PJ, Xiang AP. Mesenchymal stem cell as salvage treatment for refractory chronic GVHD. Bone Marrow Transplant. 2010; 45: 17321740.

12. Bartholomew A, Sturgeon C, Siatskas M, Ferrer K, McIntosh K, Patil S, Hardy W, Devine S, Ucker D, Deans R, Moseley A, Hoffman R. Mesenchymal stem cells suppress lymphocyte proliferation in vitro and prolong skin graft survival in vivo. Exp Hematol. 2002; 30: 42-48.

13. Casiraghi F, Azzollini N, Cassis P, Imberti B, Morigi M, Cugini D, Cavinato RA, Todeschini M, Solini S, Sonzogni A, Perico N, Remuzzi G, Noris M. Pretransplant infusion of mesenchymal stem cells prolongs the survival of a semiallogeneic heart transplant through the generation of regulatory T cells. J Immunol. 2008; 181: 3933-3946.

14. Sbano P, Cuccia A, Mazzanti B, Urbani S, Giusti B, Lapini I, Rossi L, Abbate R, Marseglia G, Nannetti G, Torricelli F, Miracco C, Bosi A, et al. Use of donor bone marrow mesenchymal stem cells for treatment of skin allograft rejection in a preclinical rat model. Arch Dermatol Res. 2008; 300: 115-124.

15. Crop MJ, Baan CC, Korevaar SS, Ijzermans JN, Alwayn IP, Weimar W, Hoogduijn MJ. Donor-derived mesenchymal stem cells suppress alloreactivity of kidney transplant patients. Transplantation. 2009; 87: 896-906.

16. Tan J, Wu W, Xu X, Liao L, Zheng F, Messinger S, Sun X, Chen J, Yang S, Cai J, Gao X, Pileggi A, Ricordi C. Induction therapy with autologous mesenchymal stem cells in living-related kidney transplants: a randomized controlled trial. JAMA. 2012; 307: 1169-1177.

17. Zhao WY, Zhang L, Han S, Zhu YH, Wang LM, Zhou MS, Zeng L. Evaluation of living related kidney donors in China: policies and practices in a transplant center. Clin Transplant. 2010; 24: E158-162.

18. Schreiber SL, Crabtree GR. The mechanism of action of cyclosporin A and FK506. Immunol Today. 1992; 13: 136142.

19. Liu EH, Siegel RM, Harlan DM, O'Shea JJ. T cell-directed therapies: lessons learned and future prospects. Nat 
Immunol. 2007; 8: 25-30.

20. Williams D, Haragsim L. Calcineurin nephrotoxicity. Adv Chronic Kidney Dis. 2006; 13: 47-55.

21. Staatz C, Taylor P, Tett S. Low tacrolimus concentrations and increased risk of early acute rejection in adult renal transplantation. Nephrol Dial Transplant. 2001; 16: 19051909.

22. Undre NA, van Hooff J, Christiaans M, Vanrenterghem Y, Donck J, Heeman U, Kohnle M, Zanker B, Land W, Morales JM, Andrés A, Schäfer A, Stevenson P. Low systemic exposure to tacrolimus correlates with acute rejection. Transplant Proc. 1999; 31: 296-298.

23. Richards KR1, Hager D, Muth B, Astor BC, Kaufman D, Djamali A. Tacrolimus trough level at discharge predicts acute rejection in moderately sensitized renal transplant recipients. Transplantation. 2014; 97: 986-991.

24. Ankrum JA, Ong JF, Karp JM. Mesenchymal stem cells: immune evasive, not immune privileged. Nat Biotechnol. 2014; 32: 252-260.

25. Popp FC, Eggenhofer E, Renner P, Slowik P, Lang SA, Kaspar H, Geissler EK, Piso P, Schlitt HJ, Dahlke MH. Mesenchymal stem cells can induce long-term acceptance of solid organ allografts in synergy with low-dose mycophenolate. Transpl Immunol. 2008; 20: 55-60.

26. Di Nicola M, Carlo-Stella C, Magni M, Milanesi M, Longoni PD, Matteucci P,Grisanti S, Gianni AM. Human bone marrow stromal cells suppress T-lymphocyte proliferation induced by cellular or nonspecific mitogenic stimuli. Blood. 2002; 99: 3838-3843.

27. Perico N, Casiraghi F, Introna M, Gotti E, Todeschini M, Cavinato RA, Capelli C, Rambaldi A, Cassis P, Rizzo $\mathrm{P}$, Cortinovis M, Marasà M, Golay J, et al. Autologous mesenchymal stromal cells and kidney transplantation: a pilot study of safety and clinical feasibility. Clin J Am Soc Nephrol. 2011; 6: 412-422.

28. Reinders ME, de Fijter JW, Roelofs H, Bajema IM, de Vries DK, Schaapherder AF, Claas FH, van Miert PP, Roelen DL, van Kooten C, Fibbe WE, Rabelink TJ. Autologous bone marrow-derived mesenchymal stromal cells for the treatment of allograft rejection after renal transplantation: results of a phase I study. Stem Cells Transl Med. 2013; 2: 107-111.

29. Reinders ME, Bank JR, Dreyer GJ, Roelofs H, Heidt S, Roelen DL, Al Huurman V, Lindeman J, van Kooten C, Claas FH, Fibbe WE, Rabelink TJ, de Fijter JW. Autologous bone marrow derived mesenchymal stromal cell therapy in combination with everolimus to preserve renal structure and function in renal transplant recipients. J Transl Med. 2014; 12: 331 .

30. Hoogduijn MJ, Crop MJ, Korevaar SS, Peeters AM, Eijken M, Maat LP, Balk AH, Weimar W, Baan CC. Susceptibility of human mesenchymal stem cells to tacrolimus, mycophenolic acid, and rapamycin. Transplantation. 2008; 86: $1283-1291$.
31. Pidala J, Kim J, Jim H, Kharfan-Dabaja MA, Nishihori T, Fernandez HF, Tomblyn M, Perez L, Perkins J, Xu M, Janssen WE, Veerapathran A, Betts BC, et al. A randomized phase II study to evaluate tacrolimus in combination with sirolimus or methotrexate after allogeneic hematopoietic cell transplantation. Haematologica. 2012; 97: 1882-1889.

32. Baron F, Lechanteur C, Willems E, Bruck F, Baudoux E, Seidel L, Vanbellinghen JF, Hafraoui K, Lejeune M, Gothot A, Fillet G, Beguin Y. Cotransplantation of mesenchymal stem cells might prevent death from graft-versus-host disease (GVHD) without abrogating graft-versus-tumor effects after HLA-mismatched allogeneic transplantation following nonmyeloablative conditioning. Biol Blood Marrow Transplant. 2010; 16: 838-847.

33. Ning H, Yang F, Jiang M, Hu L, Feng K, Zhang J, Yu Z, Li B, Xu C, Li Y, Wang J, Hu J, Lou X, et al. The correlation between cotransplantation of mesenchymal stem cells and higher recurrence rate in hematologic malignancy patients: outcome of a pilot clinical study. Leukemia. 2008; 22: 593599.

34. Choi SW, Reddy P. Current and emerging strategies for the prevention of graft-versus-host disease. Nat Rev Clin Oncol. 2014; 11: 536-547.

35. De Martino M, Zonta S, Rampino T, Gregorini M, Frassoni F, Piotti G, Bedino G, Cobianchi L, Dal Canton A, Dionigi $\mathrm{P}$, Alessiani M. Mesenchymal stem cells infusion prevents acute cellular rejection in rat kidney transplantation. Transplant Proc. 2010; 42: 1331-1335.

36. Kunter U, Rong S, Boor P, Eitner F, Müller-Newen G, Djuric Z, van Roeyen CR, Konieczny A, Ostendorf T, Villa L, Milovanceva-Popovska M, Kerjaschki D, Floege J. Mesenchymal stem cells prevent progressive experimental renal failure but maldifferentiate into glomerular adipocytes. J Am Soc Nephrol. 2007; 18: 1754-1764.

37. Ferlicot S, Vernochet A, Romana S, Ortin-Serrano M, Letierce A, Brégerie O, Durrbach A, Guettier C. Microchimerism in renal allografts: clinicopathological associations according to the type of chimeric cells. Histopathology. 2010; 56: 188-197.

38. Newell KA, Asare A, Kirk AD, Gisler TD, Bourcier K, Suthanthiran M, Burlingham WJ, Marks WH, Sanz I, Lechler RI, Hernandez-Fuentes MP, Turka LA, SeyfertMargolis VL; Immune Tolerance Network ST507 Study Group. Identification of a B cell signature associated with renal transplant tolerance in humans. J Clin Invest. 2010; 120: 1836-1847.

39. Pallier A, Hillion S, Danger R, Giral M, Racapé M, Degauque N, Dugast E, Ashton-Chess J, Pettré S, Lozano JJ, Bataille R, Devys A, Cesbron-Gautier A, et al. Patients with drug-free long-term graft function display increased numbers of peripheral B cells with a memory and inhibitory phenotype. Kidney Int. 2010; 78: 503-513.

40. Peng Y, Ke M, Xu L, Liu L, Chen X, Xia W, Li X, Chen Z, Ma J, Liao D, Li G, Fang J, Pan G, et al. Donorderived mesenchymal stem cells combined with low- 
dose tacrolimus prevent acute rejection after renal transplantation: a clinical pilot study. Transplantation. 2013; 95: 161-168.

41. Delmonico F, Council of the Transplantation, S. A Report of the Amsterdam Forum On the Care of the Live Kidney Donor: Data and Medical Guidelines. Transplantation. 2005; 79: 53-66.

42. Yu W, Chen Z, Zhang J, Zhang L, Ke H, Huang L, Peng Y, Zhang X, Li S, Lahn BT, Xiang AP. Critical role of phosphoinositide 3-kinase cascade in adipogenesis of human mesenchymal stem cells. Mol Cell Biochem. 2008; 310: 11-18.

43. Zhang AX, Yu WH, Ma BF, Yu XB, Mao FF, Liu W, Zhang JQ, Zhang XM, Li SN, Li MT, Lahn BT, Xiang AP. Proteomic identification of differently expressed proteins responsible for osteoblast differentiation from human mesenchymal stem cells. Mol Cell Biochem. 2007; 304: 167-179. 